\title{
The Practical Context of Teaching Staff in Ethnic Minority Boarding Secondary Schools in An Giang Province, Vietnam
}

\author{
Thang Bach Nguyen ${ }^{1,2}$ \\ ${ }^{1}$ Faculty of Education, An Giang University, \\ ${ }^{2}$ Vietnam National University - Ho Chi Minh City, Vietnam
}

\begin{abstract}
Over the years, the work of building, fostering and developing teachers of managers in An Giang education sector has achieved many remarkable results. However, besides the achievements, the teaching staffs in Secondary Ethnic Boarding Schools is not synchronized in quality and reasonable in structure; this article researched on the reality of ethnic minority teachers in An Giang province, thereby proposing a number of recommendations to improve their quality in order meet the requirements of education innovation today.
\end{abstract}

Key words:teaching staffs, ethnic boarding, secondary school

\section{Introduction}

An Giang is a province in the Southwest region, with a particularly important geographical and political position of the mountains, bordering the Kingdom of Cambodia, An Giang has a large number of Khmer ethnic people living, the development of teaching staff at ethnic minority boarding schools in An Giang province, ensuring the assigned duties, meeting the province's socio-economic development requirements has become an important and necessary issue. The author researches the current situation of teachers in ethnic minority secondary schools in the province.

\section{The number of teaching staff}

The number of teachers in ethnic minority boarding secondary schools in An Giang province is as Table 2.1 .

According to factual statistics for the academic year 2019-2020, the ethnic minority boarding secondary schools in An Giang province have 64 teachers, the average ratio of teachers/class in 02 ethnic minority schools in An Giang province is 2.25 and 2.33 respectively (the average of both schools is 2.29), ensuring that 02 schools have enough teachers to teach in all subjects and other educational activities as prescribed.

In general, the number of teachers is favorable in the process of performing teaching and other educational tasks in schools.

Table 2.1The number of teaching staff for the academic year 2019 - 2020

\begin{tabular}{|c|c|c|c|c|c|}
\hline Schools & School leaders & Teachers & Students & Class & $\begin{array}{c}\text { Ratio } \\
\text { Teacher/class }\end{array}$ \\
\hline $\begin{array}{l}\text { Tri TonEthnic } \\
\text { Minority Boarding } \\
\text { Secondary School }\end{array}$ & $\begin{array}{c}3 \\
\text { (1 Khmer ethnic) }\end{array}$ & 36 & 511 & 16 & 2.25 \\
\hline $\begin{array}{l}\text { Tinh Bien Ethnic } \\
\text { Minority Boarding } \\
\text { Secondary School }\end{array}$ & $\begin{array}{c}3 \\
\text { (1 Khmer ethnic) }\end{array}$ & 28 & 360 & 12 & 2.33 \\
\hline Total & 6 & 64 & 871 & 28 & 2.29 \\
\hline
\end{tabular}

\section{The structure of the teaching staff}

3.1 The structure of the teaching staff by gender and ethnicity

Regarding ethnic structure: According to statistics (Table 3.1) the ethnic minority boarding secondary schools in An Giang province have a total of 64 teachers with 19 teachers being Khmer, concentrated in Tri Ton Secondary Ethnic Minority High School and the number in high schools. Tinh Bien Secondary School ethnic minority is 9 teachers. 
Table 3.1 Structure of teaching staff by gender and ethnicity in the academic year 2019-2020

\begin{tabular}{lccccccccc}
\hline \multicolumn{1}{c}{ Schools } & $\begin{array}{c}\text { Academic } \\
\text { year }\end{array}$ & Teachers & Female & $\begin{array}{c}\text { Ratio } \\
\mathbf{\%}\end{array}$ & Male & $\begin{array}{c}\text { Ratio } \\
\mathbf{\%}\end{array}$ & Ethnic & $\begin{array}{c}\text { Ratio } \\
\mathbf{\%}\end{array}$ \\
\hline $\begin{array}{l}\text { Tri TonEthnic } \\
\text { Minority Boarding } \\
\text { Secondary School }\end{array}$ & $2019-2020$ & 36 & 21 & 58.3 & 15 & 41.7 & 19 & 52.8 \\
\hline $\begin{array}{l}\text { Tinh Bien Ethnic } \\
\text { Minority Boarding } \\
\text { Secondary School }\end{array}$ & $2019-2020$ & 28 & 12 & 42.9 & 16 & 57.1 & 9 & 32.1 \\
\hline \multicolumn{1}{c}{ Total } & $\mathbf{2 0 1 9 - 2 0 2 0}$ & $\mathbf{6 4}$ & $\mathbf{3 3}$ & $\mathbf{5 1 . 6}$ & $\mathbf{3 1}$ & $\mathbf{4 8 . 4}$ & $\mathbf{2 8}$ & $\mathbf{4 3 . 8}$ \\
\hline
\end{tabular}

Accordingly, the general ratio of the two schools in terms of the structure of teachers of ethnic minorities (ethnic minorities) compared to the total number of teachers is appropriate. Analyzing each school separately, presents:

The school with the largest percentage of Khmer ethnic teachers is Tri Ton Ethnic Minority Boarding Secondary School with 19 teachers, 52.8\%, high compared to the total number of teachers of this school; Tinh Bien Ethnic Minority Secondary School has 9 teachers of Khmer ethnicity, the rate is $32.1 \%$. The structure of Khmer ethnic minority teachers in this school is not reasonable compared to the total number of teachers of the school.

In the future, the principal of Tri Ton Ethnic Minority Boarding Secondary School needs to keep a stable level or take measures to screen and transfer Khmer ethnic teachers; At the same time, the principal of Tinh Bien Ethnic Minority Boarding Secondary School needs to pay more attention to the development of the number of Khmer ethnic teachers in the school, as well as consult with the governing agencies in planning and training. created to develop more teachers who are ethnic Khmer to meet teaching in the following years.

Gender structure: According to general statistics of 02 schools, out of 64 teachers, there are 33 female teachers (51.6\% rate) and 31 male teachers $(48.4 \%)$. The gender structure is quite balanced and appropriate. However, the structure of male and female teachers in each school has a significant gender imbalance in the teaching staff:
Secondary School has 36 teachers, including 21 female teachers, accounting for $58.3 \%$ and 15 male teachers accounting for $41.7 \%$.

- Tinh Bien Ethnic Minority Boarding Secondary School has 28 teachers, of which there are only 12 female teachers, accounting for $42.9 \%$ and 16 male teachers, accounting for $57.1 \%$.

This is a difficulty in performing the duties of teachers in each school, because ethnic minority students need a teacher to directly manage and take turns to take care of them 24 hours a day. While female teachers will be busy taking care of the family (Tri Ton Ethnic Minority Boarding Secondary School), male teachers also have difficulty taking care of female students.

Therefore, in the planning and selection of teachers in the coming time, school principals need to pay attention to the gender balance in the teaching staff.

3.2 The structure of age and working seniority Table 3.2 shows that the teachers in both two ethnic minority high schools in An Giang province have an unreasonable distribution of age, specifically:

The number of teachers with working experience from 5 to 20 years is 52 people (accounting for $81.3 \%$ ) and 53 people aged 30 to 50 $(82.8 \%)$ account for the highest percentage. This is the period when the teachers have had working experience and are at a stable age in terms of health conditions, intellectual maturity and experience.

Table 3.2 Working seniority and age of teaching staff

\begin{tabular}{|c|c|c|c|c|c|c|c|}
\hline \multirow{2}{*}{ Schools } & \multirow{2}{*}{ Teachers } & \multicolumn{3}{|c|}{ Working seniority } & \multirow[b]{2}{*}{$\begin{array}{c}\text { Under } \\
\mathbf{3 0} \\
\end{array}$} & \multicolumn{2}{|c|}{ Age } \\
\hline & & $\begin{array}{c}\text { under } 5 \\
\text { years }\end{array}$ & $\begin{array}{l}5-20 \\
\text { years }\end{array}$ & $\begin{array}{c}\text { Over } \\
20 \text { years }\end{array}$ & & $\begin{array}{c}\text { From } 30 \text { to } \\
50 \\
\end{array}$ & Over 50 \\
\hline $\begin{array}{l}\text { Tri Ton Ethnic Minority } \\
\text { Boarding Secondary School }\end{array}$ & 36 & 2 & 27 & 7 & 4 & 28 & 4 \\
\hline $\begin{array}{l}\text { Tinh Bien Ethnic Minority } \\
\text { Boarding Secondary School }\end{array}$ & 28 & 0 & 25 & 3 & 1 & 25 & 2 \\
\hline Total & 64 & 2 & 52 & 10 & 5 & 53 & 6 \\
\hline
\end{tabular}


considered an appropriate rate. At this age, teachers are experienced and are the core professional force for schools.

The force of young teachers in ethnic minority high schools is still too small, the number of teachers with less than 5 years of working experience is only 2 teachers (accounting for $3.1 \%$ ) and 5 teachers under the age of 30 (accounting for $7.8 \%$ ). This is the core force in youth movements with the strength of enthusiasm and dynamism in innovation in schools.

If the age of less than 30 years is considered enthusiastic, dynamic, creative and vibrant in performing tasks, the age from 30 to 50 is considered as the age of maturity, calmness and experience in work. The good combination of these two ages will make the school really have creative, dynamic and experienced teachers in all school activities.

However, the proportion of teaching staff between these two age groups is not equal, the difference is too large in number, the percentage of

\section{ISSN 2455-6378}

under 30 years old is too small. Therefore, in the coming time, in the planning of teachers, the principals of schools need to pay attention to develop (in terms of quantity and quality) for young teachers to make the difference between these two age groups smaller, in order to harmonize enthusiasm, energy and work experience, promoting educational development in schools.

\section{The quality of the teaching staff}

4.1 The professional qualification

According to Table 4.1: Most teachers of ethnic minority high schools in An Giang province meet the standards of training qualifications, university degree accounts for $95.3 \%$, college level has 01 teacher at Tri Ton Secondary Ethnic Minority High School. standard qualifications compared to the needs of the position). The number of teachers with standard qualifications accounted above for a rather modest rate, accounting for $3.1 \%$.

Table 4.1 Professional training qualifications of teachers in the academic year 2019 - 2020

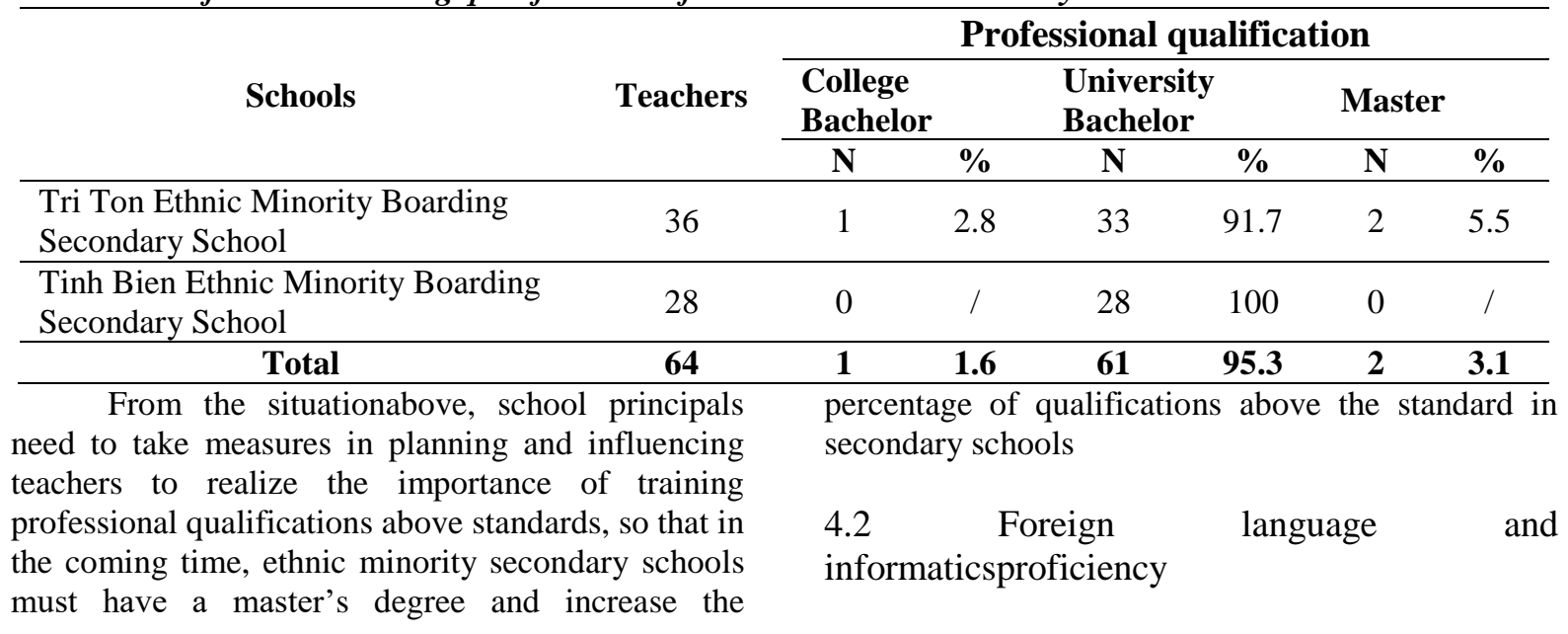

Table 4.2 Foreign language proficiency (English) of teaching staff

\begin{tabular}{lccccccc}
\hline \multicolumn{1}{c}{ Schools } & Teachers & Level A & $\begin{array}{l}\text { Level } \\
\text { B/A2 }\end{array}$ & $\begin{array}{c}\text { Level } \\
\text { C/B1 }\end{array}$ & Bachelor & Master & None \\
\hline $\begin{array}{l}\text { Tri TonEthnic Minority } \\
\text { Boarding Secondary }\end{array}$ & 36 & 1 & 18 & 3 & 4 & 0 & 10 \\
$\begin{array}{l}\text { School } \\
\text { Tinh Bien Ethnic Minority } \\
\begin{array}{l}\text { Boarding Secondary } \\
\text { School }\end{array}\end{array}$ & 28 & 24 & 2 & 0 & 2 & 0 & 0 \\
\hline Total & $\mathbf{6 4}$ & $\mathbf{2 5}$ & $\mathbf{2 0}$ & $\mathbf{3}$ & $\mathbf{6}$ & $\mathbf{0}$ & $\mathbf{1 0}$ \\
\hline
\end{tabular}

Table 4.3 Informatics proficiency of teaching staff

\begin{tabular}{lccccccc}
\multicolumn{1}{c}{ Schools } & Teachers & Level A & Level B & Level C & Bachelor & Master & None \\
\hline $\begin{array}{l}\text { Tri TonEthnic Minority } \\
\text { Boarding Secondary } \\
\text { School }\end{array}$ & 36 & 34 & 1 & $/$ & 1 & $/$ & $/$ \\
\hline $\begin{array}{l}\text { Tinh Bien Ethnic } \\
\begin{array}{l}\text { Minority Boarding } \\
\text { Secondary School }\end{array}\end{array}$ & 28 & 27 & $/$ & $/$ & 1 & $/$ & $/$ \\
\hline \multicolumn{1}{c}{ Total } & $\mathbf{6 4}$ & $\mathbf{6 1}$ & $\mathbf{1}$ & $/$ & $\mathbf{2}$ & $\mathbf{0}$ & $\mathbf{0}$ \\
\hline
\end{tabular}


The survey results in Table 4.2 and Table 4.3 show that the majority of teachers in An Giang province's ethnic minority secondary schools have basic foreign language skills (mainly English) that meet the requirements (as specified in Circular No. 01/2014/TT-BGDDT on January 24, 2014 of the Minister of Education and Training promulgating the 6-level foreign language competency framework for Vietnam) and the standard of computer skills in basic IT skills (according to the provisions of Circular

\section{ISSN 2455-6378}

03/2014/TT-BTTTT on March 11, 2014 regulating standards of skills in using information technology).

However, there are still 10 teachers, the rate of $15.6 \%$ do not have certificates or foreign language degrees as prescribed. This problem may cause difficulties for teachers when they have to apply their knowledge of foreign languages to improve their professional and professional quality in accessing the new educational program in the near future.

Table 4.4 The statistics of Khmer language proficiency of teaching staff in the academic year 2019 - 2020

\begin{tabular}{ccccc}
\hline Schools & Teachers & Certificate & Bachelor & None \\
\hline $\begin{array}{l}\text { Tri TonEthnic Minority Boarding } \\
\text { Secondary School }\end{array}$ & 36 & 18 & 2 & 16 \\
\hline $\begin{array}{l}\text { Tinh Bien Ethnic Minority } \\
\text { Boarding Secondary School }\end{array}$ & 28 & 24 & 2 & 2 \\
\hline Total & $\mathbf{6 4}$ & $\mathbf{5 2}$ & $\mathbf{4}$ & $\mathbf{1 8}$ \\
\hline $\boldsymbol{\%}$ & 100 & 81.3 & 6.3 & 12.4 \\
\hline
\end{tabular}

According to statistics (Table 4.4): The number of teachers with certificates of Khmer language issued by the Department of Education and Training of An Giang province is 52 teachers, the rate is $81.3 \%$; The number of teachers without Khmer language certificates is 18 teachers, accounting for $12.4 \%$ (most is at Tri Ton Ethnic Minority Boarding Secondary School).

Thus, the percentage of teachers who do not have Khmer language certificates accounts for a very high rate, up to $12.4 \%$ of teachers do not meet the Khmer language standards as prescribed in Article 15 - Regulations on organization and operation of ethnic minority high schools, promulgated together with Circular No. 01/2016/TT-BGDDT dated January 15, 2016 of the Ministry of Education and Training. Concentrated mainly at Tri Ton Ethnic Minority Boarding Secondary School.

The total number of teachers directly teaching Khmer language to students according to the 7-book program - regulations of the Ministry of Education and Training in 02 schools is currently 04 teachers, of which only 02 teachers have a Bachelor's degree in Khmer pedagogy and 02 teachers have a bachelor's degree in Khmer language pedagogy. not yet trained. Teachers of these schools need to be acutely aware that:

- Khmer language is the best condition for teachers to actively learn about local culture, language, customs, practices and psychological characteristics of ethnic minority students.

- Khmer language is one of the appropriate conditions for teachers to apply teaching methods, forms of teaching organization and assessment, suitable for ethnic minority high school students; participate in the management and education of students outside of regular school hours; fostering and tutoring students; guide students to self-study; organize labor activities and creative experiences for students.

In the future, the principals of these schools need to take urgent measures in planning and make a drastic impact so that teachers can actively study Khmer. This is the duty and authority of teachers working at ethnic minority boardingschools.

\subsection{The qualificationof political theory}

Table 4.5 Statistics of party members, qualifications of political theory, certificates of fostering educational management of leaders and teachers

\begin{tabular}{|c|c|c|c|c|c|c|}
\hline \multirow[b]{2}{*}{ Schools } & \multirow{2}{*}{$\begin{array}{l}\text { Pincipals, } \\
\text { Teachers }\end{array}$} & \multirow{2}{*}{$\begin{array}{c}\text { Party } \\
\text { members }\end{array}$} & \multicolumn{3}{|c|}{ Qualifications of political theory } & \multirow{2}{*}{$\begin{array}{c}\text { Certificates of } \\
\text { fostering } \\
\text { educational } \\
\text { management }\end{array}$} \\
\hline & & & Senior & $\begin{array}{c}\text { Intermediat } \\
\mathbf{e} \\
\end{array}$ & Primary & \\
\hline $\begin{array}{l}\text { Tri TonEthnic Minority } \\
\text { Boarding Secondary School }\end{array}$ & $\begin{array}{c}36 \\
\text { (3 leaders) }\end{array}$ & 21 & $\begin{array}{c}1 \\
\text { (1 leaders) }\end{array}$ & $\begin{array}{c}3 \\
\text { (2 leaders) }\end{array}$ & 22 & $\begin{array}{c}6 \\
\text { (3 leaders) }\end{array}$ \\
\hline $\begin{array}{l}\text { Tinh Bien Ethnic Minority } \\
\text { Boarding Secondary School }\end{array}$ & $\begin{array}{c}28 \\
\text { (3 leaders) }\end{array}$ & 28 & 0 & $\begin{array}{c}6 \\
\text { (3 leaders) }\end{array}$ & 11 & $\begin{array}{c}4 \\
\text { (3 leaders) }\end{array}$ \\
\hline Total & 64 & 59 & 1 & 9 & 33 & 10 \\
\hline $\begin{array}{l}\text { According to statistics } \\
\text { percentage of party members } \\
\text { teachers in ethnic minority b } \\
\text { at } 59 / 64(92.3 \%) \text {; all } 6 \text { lead } \\
\text { passed the training co }\end{array}$ & $\begin{array}{l}\text { in Table } \\
n \text { the leader } \\
\text { arding scho } \\
\text { s of } 02 \mathrm{scl} \\
\text { se on e }\end{array}$ & $\begin{array}{l}\text { 4.5: The } \\
\text { ship team, } \\
\text { ols is high } \\
\text { ools have } \\
\text { ducational }\end{array}$ & \multicolumn{4}{|c|}{$\begin{array}{l}\text { management and political theory from intermediate } \\
\text { level upwards (including } 01 \text { senior). The level of } \\
\text { political theory from elementary to higher in teachers } \\
\text { also accounts for a fairly high rate of } 33 / 64(51.5 \%) \text {. } \\
\text { The core force in the schools is also gradually trained }\end{array}$} \\
\hline
\end{tabular}


through the intermediate level of political and educational management, ready to be the successor of the management staff.

In general, statistics show that: teachers in ethnic minority secondary schools in An Giang province are interested by leaders at all levels and branches in training political theory and developing party members. This shows that the teachers of the ethnic minority boarding schools have a high reputation for their political, moral and lifestyle qualities.

\section{Recommendations to improve the quality of teaching staff at ethnic minority boarding secondary schools}

5.1For the People's Committee of An Giang province and local authorities

There are more drastic measures to direct the implementation of the Plan No. 56/KH-UBND dated February 10, 2017, the Plan on the continuation of the implementation of the Plan "Consolidation and development of the domestic ethnic minority boarding school system". residing in An Giang province in the period 2016 - 2020"; Plan No. 415/KH-UBND on July 13, 2017, Plan to implement the project "Training and fostering teachers and educational institution managers to meet the requirements of fundamental and comprehensive reform of general education in the period of 20172020 , with a vision to 2025 " in An Giang province.

On that basis, raise the sense of responsibility for leaders of departments and unions for improving the quality of education of ethnic minority secondary schools; improve the quality of teachers in these schools.

Increase the budget to invest in facilities, teaching equipment, teaching materials, information technology means; creating favorable conditions for teachers to develop according to professional standards, meeting the requirements of teaching and learning according to the overall educational program.

Having specific policies and appropriate priorities to encourage cadres and teachers to volunteer to work in ethnic minority secondary schools; attract ethnic minority teachers to work in ethnic minority high schools. Encourage ethnic minority teachers to go to school to improve their qualifications.

It is time for the Provincial People's Committee to have specific regulations on the structure of ethnic minority teachers in the teaching staff of ethnic minority secondary schools. Based on this regulation and other practical conditions, educational management agencies and principals of ethnic minority secondary schools will select, use, and screen teachers to more effectively respond to requirements and educational development of schools.

Gradually increase the proportion of ethnic minority administrators and teachers in educational management agencies, educational institutions in areas with a large number of ethnic minorities, especially ethnic minority secondary schools.

It is necessary to build one more district-level Ethnic Minority high school for the Cham ethnic group, as a source of enrollment of Cham students into An Giang high school for ethnic minorities.

\subsection{For Provincial Committee for Ethnic} Minority Affairs and District Ethnic Affairs Departments

Strengthen propaganda to raise awareness and responsibility of the Party committees, local authorities and the community about investing in consolidating and improving the quality of education of the ethnic minority boarding secondary school system to meet the needs of the community. requirements for education and training innovation; about the goals and specific characteristics of the ethnic minority boarding school and the responsibilities of each object in the process of working and studying at the school.

Raise the awareness of parents of students in the education of children of ethnic minorities, promote the role of the representative board of parents and social forces to support schools.

The Provincial Committee for Ethnic Minority Affairs, the Department of Ethnic Minority Affairs and the Study Promotion Association in the localities are important bridges between the school and the families of ethnic minority students. As a result, ethnic minority boarding secondary schools can overcome challenges and fulfill tasks such as: coordinating with local authorities and political organizations more conveniently; conduct better socialization work; school enrollment; mobilize resources for school development.

If the "bridges" on the activities are close, rhythmic, regular and enthusiastic, they will contribute a great deal to the ethnic minority boarding school to become the dreams and aspirations of ethnic minority students in the provinces of the province.

\subsection{For An Giang Department of Education and} Training, Departments of Education and Training (localities of ethnic minority boarding secondary schools)

More attention should be paid to the selection of teachers to work at the ethnic minority boardingsecondary school to ensure sufficient quantity, uniformity in structure, standardization of training qualifications, stability in political thought and expertise in the field of education. pedagogic. Strengthening training and fostering teachers on innovating teaching methods in accordance with psycho-physiological characteristics, promoting dynamism, initiative and creativity of students.

It is necessary to give more autonomy to principals of ethnic minority secondary schools in 
implementing the autonomy, self-responsibility for task performance, and to organize an active and creative school apparatus. Principals can be proactive in recruiting private teachers for ethnic minority high schools in the same way as recruiting teachers for specialized schools in the province.

Implement regimes and policies to ensure the rights and obligations of teachers and students of ethnic minority boardingsecondary schools such as: organizing for teachers to attend professional training courses and new teaching methods inside and outside the province; encourage and motivate teachers to study above standards and improve their professional qualifications; exchange and learning experiences between ethnic minority secondary schools in the Mekong Delta and other regions.

Special priority should be given to teachers of ethnic minority boarding secondary schools in the plan to build and form key teachers at provincial and district levels such as subject councils, professional inspection collaborators, etc., should create conditions for teachers. Ethnic minority boardingsecondary schools are allowed to participate.

Strengthening the equipment of modern teaching facilities to ensure that teachers have adequate materials and reference books in teaching. Research and develop a set of specific professional standards for teachers of ethnic minority secondary schools to use as a basis for management, training, fostering, testing and evaluation, etc., to develop teaching staff.

\subsection{For Ethnic Minority Boarding Secondary} Schools

Principals need to organize planning and rational use of teachers; advise and propose to the Department of Education and Training to have an objective and scientific method of selection to be able to have qualified teachers, solid pedagogical skills in addition to the standards of ethics and lifestyle. and conditions to perform well the task of educating students in ethnic minority boarding secondary schools; have a mechanism to attract good teachers to ethnic minority high schools.

Board of leaders should organize for teachers to learn about ethnic languages to meet the criteria of professional standards. High school teachers teach in ethnic minority boarding schools, focusing on training teachers with university and post-graduate degrees in ethnic languages. In addition, it is necessary to foster more culture of ethnic minorities to improve the quality of education in schools.
ISSN 2455-6378

\section{References}

[1] Ministry of Education and Training (2016). Regulations on organization and operation of boarding high schools for ethnic minorities, issued together with Circular No. 01/2016/TT-BGDDT, dated January 15, 2016. Hanoi.

[2] Ministry of Education and Training (2017). Circular guiding the list of job position frameworks and norms of the number of people working in public general education institutions. Circular No: 16/2017/TT-BGDDT dated 12 July 2017. Hanoi.

[3] Nguyen,B. T,\& Le, T.T. (2018). Theoretical basis for developing the teaching staff according to the human resource management approach. Vietnam Education Publishing House.

[4] Nguyen, M.Đ. (2012). Systematic approach in research and development of human resources.January 2012 (76). Journal of Education Science.

[5] People's Committee of An Giang province (2017). The plan "Consolidate and develop the system of boarding schools for ethnic minorities in An Giang province in the 2016-2020 period". Plan No. 56/KH- People's Committee dated February 10, 2017. 